\title{
An Analysis of Supermarket Pricing: The Case of Selected Supermarkets in Gaborone, Botswana
}

\author{
Sathyamoorthi C.R. \& Mburu P. T. \\ Faculty of Business \\ University of Botswana
}

Received: Feb. 24, 2016

Accepted: March 13, 2016

Published: April 1, 2016

doi:10.5296/jmr.v8i2.9089

URL: http://dx.doi.org/10.5296/jmr.v8i2.9089

\begin{abstract}
The purpose of study is to explore price fluctuations (tracking of pricing trends) in essential consumer items among identified Supermarkets in Gaborone. The prices were read from shop displays at the beginning of the month, mid-month and at the end of the month. A triangulation methodology was utilised as it strengthened and confirmed results. Seven major supermarkets were selected for the study while a mall intercept survey was used to find out the consumer store and brand selection in relation to pricing strategies adopted by the store.

The study revealed that there were price fluctuations and differences between selected supermarkets during the selected period of study as well as amongst branches within a supermarket. Supermarkets utilised pricing for promotional than other element of retail mix. The results indicate that Promo pricing strategy was preferred by both stores and customers compared to Everyday Low Price (EDLP) and High-Low Pricing. While consumers shopped at the beginning and the end of the month looking at the price, mid-month shopping was done more looking at other retail mix elements. With well-educated customer's base, EDLP and $\mathrm{H} / \mathrm{L}$ pricing may not work as customers would be looking for the extras in the retail mix. The findings also indicated that consumers were aware of price differences and engaged in shopping in an opportunistic manner (cherry pickers).
\end{abstract}

Keywords: Price Fluctuations, Pricing Strategy, Everyday Low Price, Promo Price, Supermarkets 


\section{Introduction}

Supermarkets are traditionally viewed by development economists, policy makers and practitioners as the rich world's place to shop (Reardon et al 2004). The rise of supermarkets in developing countries has received considerable attention in the developing economies' literature over the past few years (Azad et al 2012). The rapid rise of supermarkets in Africa is made possible by urbanization and the rise of the middle class in countries such as South Africa and Kenya; but goes well beyond those drivers, as supermarkets are now extending into poor neighbourhoods of large cities and towns all-round the developing world, including Africa. With the adaptation and efficient procurement systems, the new trend in the region is "supermarket to the poor"; diffusion and extension of supermarkets away from luxury high-end niches to being mass market merchandisers (Weatherspoon \& Reardon, 2003).

\section{Super markets in Botswana}

Do It In Africa (2016) indicates that there are over 100 supermarkets in Botswana with some big supermarkets having branches spread all over the country. The most popular supermarkets with many braches in different parts of Botswana include Checkers, Choppies, Pay-less Supermarket, Pick 'n Pay, Shoppers, Shoprite and Spar.

Choppies is the fast growing retail stores in Africa, outside South Africa. Choppies was formed in 1986 in a Botswana Town called Lobatse. The first store was Wayside supermarket. From 1993, Choppies embarked on a great expansion drive, with new stores being opened in the greater Gaborone periphery. The expansion also moved to highly populated geographical areas of Botswana. It has established a strong base in Botswana and is the largest and rapidly growing retailer which has opened stores in South Africa, Zimbabwe, Zambia and Tanzania. Currently, the group operates over 100 retail outlets in Southern Africa. The Choppies management aims to achieve a target of over 200 stores across 6 countries by December 2016 (choppies.co.bw; The Business Weekly, 2015).

Checkers is a Fast Moving Consumer Goods retail shop. It is owned by Shoprite Holdings that operates in Southern Africa. It focuses on fresh produce and offers a wide range of food items. Checkers has a number of Hypers and supermarkets operating in South Africa, Botswana and Namibia.

The Shoprite Group opened its first store in Botswana in 1998. It offers a wide range of quality products. It is Africa's largest food retailer and has outlets in 15 countries across Africa and Indian Ocean Islands. Its main business is food retailing to consumers of all income levels, with the aim of providing all communities in Africa with food \& household items in a first-world shopping environment, at the Group's lowest possible prices.

Spar Botswana's primary focus is to provide excellent service to customers, with in-store bakery, butchery, fruit and veg and delicatessen departments. The split between service departments and non-food and dry groceries is made based on the profile of each individual store. Spar has a number of branches spread over the length and breadth of the country 
PAYLESS franchise group started its operation in Botswana in early seventies during which period it owned the only grocery shop at the Gaborone City Main Mall, known popularly as Corner Supermarket. By the year 2013, it had established six grocery stores in Botswana that created more jobs for the citizens. It is noted that the mandate of this supermarket is employment creation and thereby enable economic diversification. The group also targeted to establish by the end of year 2015, additional grocery shops in the country.

Pick ' $n$ Pay Stores is a South African based retailer that is engaged in selling food, cloth and general merchandise. It focuses on discount retail market and caters to the needs of consumers through its branches located in different parts of the country. The company conducts its grocery operations under the Pick "n Pay Family set-up and have retail stores throughout South Africa, Botswana, Swaziland and a small number in Namibia.

Shoppers are another supermarket chain that has a strong base in Botswana. The retail store has a number of branches located in different parts of Botswana. Most of the stores are located in competitive locations. The service departments are strong and have a wide range of products that cater to the needs of a wider range of customers.

\section{Problem Statement}

Supermarkets in Botswana, like all supermarkets that operate under high competition environment, sell their products at different prices at different time period. This makes it hard for consumers to choose a retail shop to buy from, looking at the different offers. Supermarket retail institutions operate under Everyday Low Price strategy, making the price the top of the retail mix. However, under the salient marketing environment, sales promotion tends to surpass the pricing in the retail mix strategy. The study sought to find out the pricing strategy adopted by the selected supermarkets and the magnitude of price fluctuations between the selected period within the same supermarket and between supermarkets. The study also aimed at explaining the significance attached to the price in the retail mix and if this is in line with the consumer disposition.

\section{Objectives of the study}

1. To find the pricing strategies used by a the selected supermarkets

2. To identify price fluctuations in selected commodities among identified supermarkets

3. To find out whether there are any clear patterns of pricing with in the branches of a supermarket or between supermarkets

4. To assess consumer awareness on regular prices and specials

5. To identify shopping patterns among consumers

\section{Scope of the study}

The study focused on identifying price fluctuations in 30 selected consumer items. Emphasis was placed on commodities that are consumed almost daily by many households. The study covered a period of one month, and prices for the selected items were collected at three 
different intervals (beginning, middle and end of the month). Seven (7) major supermarkets in Gaborone were selected for the study and data were collected from these supermarkets in the month of October 2015.

\section{Literature Review}

Price plays a major role in retail mix since consumers respond to price relative to some standard, or reference. According to Rajendran, \& Tellis,(1994), most researchers' modelling brand choice show that the standard used is based on past prices of the brand, reference prices, and the store, rather than on past prices alone. Retailers today are experimenting different pricing models to test the one that will lead to higher purchases, and enrich their retail mix.(Grewal, Roggeveen \& Nordfalt 2014). Profitability in the retail industry has become a primary issue as retailers are operating on very thin margins (Bolton, Shankar \& Montoya 2007). Retail stores are pressurised by competition and customers who have come to expect frequent price discounts, leading retailers to fall into a price-promotion trap. Grewal, Roggeveen \& Nordfalt (2014) hinted that prices are also being changed based on the prices of competitors, time of the day or even conversion rate. Competition between supermarkets appears to be much more intense than ever, as supermarkets devote $80 \%$ of their hours to managing promotions and only $20 \%$ of the retail sales come from those promotions. The knowledge on how consumers respond to price promotions is essential in making critical decisions concerning price promotions (Oliveira-Castro et al., 2008) and competition strategies among the supermarkets. Myers et al (2002) indicate that once new products become exposed to markets, competitors often enter with similar products and new process technologies that enable them to compete on price, which prompts firms to re-orient their pricing policy.

A study conducted by Ramaloto (2007), on price fluctuations in supermarkets in Botswana revealed that shops fixed prices for items that they felt as right and that a shop could have different prices for one item in three different intervals. The study further indicated that prices of products sold at supermarkets are not controlled by Government and highlighted a good degree of consumer awareness on price fluctuations as they compared prices before their shopping.

\section{Pricing models for supermarkets}

According to Fassnacht \& Husseini (2013), the pricing strategy is seen as one of the five most important priorities in retail management. While supermarkets compete along many dimensions, the pricing strategy is clearly one of the most important factors that stores take on board for their successful operation. In many retail businesses, pricing strategy can be categorised as a choice between offering relatively stable prices across a wide range of items, popularly known as Every Day Low Pricing (EDLP) or adopt a big and frequent discounts on a smaller set of items known as High-Low Pricing $(\mathrm{Hi} / \mathrm{Lo})$. Supermarkets oscillate the retail mix to enable perception of lowest price in the market by use of EDLP and Hi/Lo as pricing strategy. They also utilise other adopt elements of retail mix in their marketing techniques to attract customers such as an attractive combination of products, convenient locations and a host of other services. Retail stores dealing particularly in Grocery items function on very 
low margins and have fallen into a price-promotion ploy, pushed both by competition and consumers. Moreover, retailers operate under complex conditions, particularly because of wide varieties of products, and should therefore come up with a clear formula for their pricing strategy.

The common pricing strategies used by manufacturers and retailers as documented in the literature, (Munyoki, 1997, Hosken, et al ., 2000,Hosken and Reiffen, 2001, Hansen,2006, Ellickson, \& Misra,2008, Herrmann, Moser and Weber, 2009, Metobo, 2013), include discounts and allowances, EDLP (Every Day Low Pricing strategies), (Hi-Lo) high low pricing strategies and HYBRID strategy (Hybrid EDLP/Hi-Lo, Combination of EDLP and Hi-Lo pricing strategies) According to Ellickson, P. B., \&Misra, S. (2008), Everyday Low-price (EDLP) rely on pricing strategies such as unit pricing, price lining, resale price maintenance, leader pricing and psychological pricing as temporary price cuts, while the use of Promotional (Hi-Lo) Pricing infuses high use of specials, through manufacturer price breaks or special deals.

Supermarket pricing strategies can be classified into three general categories, which include Demand oriented pricing strategies, Cost oriented strategy or Mark-up pricing strategies and Competition oriented pricing. Generally, no supermarket would use one single pricing strategy. The diversity of merchandise categories in the market and the competitive environment requires a use of diverse strategy. Fresh produce categories require a combination of Demand Oriented Pricing Strategies and Competition Oriented Pricing, while groceries would require either EDLP (Every Day Low Pricing strategies) or, (Hi-Lo) high low pricing strategies. According to Lal, \& Rao, (1997) a supermarket can obtain higher profits by use of HYBRID strategy and PROMO strategies, setting constant low prices, leading to the high turnover and more leg-count. According to Ellickson, \&Misra, (2008) pricing strategy is best viewed as a continuum, with pure EDLP (i.e., constant margins across all categories) on one end and pure PROMO (i.e. frequent sales on all categories) at the other.

The three pricing strategies adopted by supermarket are:

- $\quad$ Everyday Low Price (EDLP): Everyday Low Price is a pricing strategy that promises customers a low price without the need to wait for promotion or discount sale weeks or comparison shopping. This approach will enhance the loyalty of the stores as well as reduce the work involved in marking down the prices. The price set generally will be within the range of a non-discounted price and the high-low discounted price. The price is expected to be consistently low across all items and the stores do not believe in promotional pricing strategies such as temporary price reductions. EDLP pricing can generally result in lower fixed costs as they require less advertisement, that are essential for promotion prices, less labour cost to effect changes in prices and much simpler pricing and inventory management systems with low overhead costs. The advantage of EDLP is that it is also easy to forecast the level of consumer demand for the products, which will alleviate stock and supply chain complications. 
- Promotional Pricing or High-Low pricing strategy: Under this pricing strategy, the price for most of the items will be marked at higher than the market price, while the store may decide to offer a limited number of items at below-market price. The strategy is characterised by deep discounting on selected categories of items at different intervals throughout the year. The logic behind this approach is the hope that whilst the customers are attracted to buy low-price items, they may end up buying some high-price items as well. The net effect of this approach is an increase in profitability of the store. It may be noted that the low-pricing is rotated among various products in short intervals so that the stores can attract different customers. The advantage of this pricing strategy is that it will result, if properly implemented in profit increase. The stores should also be mindful of the risk involved in terms of incurring losses if it is not implemented properly. Also, it may result in losing some customers once they come to know that most of the products are sold at high price. Increased marketing cost is another issue for this approach. This approach can also cause a sales crash after the promotion period.

- Hybrid Pricing: This pricing strategy combines the EDLP and Hi/Lo pricing methods where the stores choose either to vary the number of products they put on "Sale" or change the frequency of "Sales" across for some or all categories of items.

Lattin \& Ortmeyer (1991) noted that retailers use different pricing strategies to segment the market, and consumers self-select, based on their shopping behaviour. According to them, retail stores compete for the support of two types of price-sensitive consumers. One type of consumer is vigilant about prices and vigorously searches for promotional items and shops in an opportunistic manner, popularly known as "cherry pickers". They travel to different stores to obtain best deals in shopping and are attracted to discounts. They are willing to do the research to learn about discounts, and they are ready to store products when items are sold at a discount. These consumers are better reached by promotional pricing strategies. The second type of consumers are focused on buying items at a reasonable price and are not keen on spending time monitoring on day-to-day changes in prices, known as "expected-price shoppers". These price seekers make single and multi-purpose shopping trips. They are unwilling to do much pre-purchase research and less likely to stockpile discounted items. Researchers have used game theory model to formalize the motivation amongst supermarkets to seek patronage of Cherry Pickers and Expected Price Shoppers.

Herrmann, Moser and Weber (2009), Munyoki, (1997), and Metobo, (2013)noted that with the (Hi-Lo) strategies, retailers put items on special offer periodically; at the same time discounts and allowances reduce the price of the product from the list price, or gives some form of free merchandise to the buyer. This raises price variability and provide customer excitement. Although it is common for retailer to offer discounts, Hansen (2006) indicated that the level of the price discount is time dependent on the seasonality of the retail cycles, for example, prior to holidays. Sale is one of the most common terms for price discount. Hosken and Reiffen (2001) define a sale as a "temporary reduction in the price of an item that is unrelated to cost changes”. Hosken, et al. (2000) also noted that Supermarkets' pricing 
behaviour differs across categories. Over time, many individual categories display several regularities in retail pricing behaviours. First, most retail price changes reflect changes in retail margins, rather than changes in wholesale prices. Second, most price reductions tend to be short-lived.

\section{Pricing as promotional tool}

According to Jones (2004) the competitive and the cyclical nature of retail industry and the regularities in retail pricing behaviours necessitate retailer to make use of diverse pricing strategies to encourage customers and remain ahead. Ellickson, \&Misra, (2008) noted that while firms compete along many dimensions, pricing strategy is clearly one of the most important for all of them. PROMO pricing gives firms greater flexibility in clearing overstock, allows them to quickly capitalize on manufacturer discounts, and facilitates the use of consumer loyalty programs. Price discounts form part of sales promotions (Chen et al 1998). In addition, marketers need to understand the threshold effects of price discounts, that is, the minimum value of a price discount required to induce consumers to purchase the product (Blattberg et al., 1995), and to differentiate between loyal customers and switchers (Shi et al, 2005). It is estimated that 17 percent of companies engage in price discounts (Guerreiro et al., 2004) as promotional tool.

A study conducted on price difference in the European Union (EU) for selected supermarket products (2001) indicates that large price differences exist amongst some supermarkets. The study also highlights possible reasons which are divided into Natural Factors, Structural Factors and market conditions.

\section{Natural Factors}

Natural causes behind price differences are factors like local preferences, consumer search costs and transport costs. They are not the result of differences in regulation, market structure or structural differences. Local preferences and culture seem to play an important role in explaining price differences for some products. For instance, butter is more often used for cooking in the North European countries than in the South European countries (General, 2002)

\section{Structural Factors}

The factors include VAT and excise taxes, regulation on shop opening hours, labour regulation, income differences, advertising rules, regulation on land use and shop size, and other types of regulation affecting the cost of selling supermarket products.

\section{Market conditions}

These conditions relate to factors that may allow producers, wholesalers and retailers to depart from the price one would expect to find in a perfectly competitive market where prices would just differ due to structural and natural causes. 
Another variable that has an impact on prices is the selling area, in the sense that economies of scale lead to lower prices. Ellickson and Misra (2008) found strong evidence that firms cluster by strategy by choosing actions that agree with those of its rivals.

\section{Other factors}

\section{Different distributor pricing}

The price paid by supermarkets for the same product differs from one supermarket to another. Some pay the catalogue price, while others receive a blanket discount for the all products of a certain distributor on account of high-volume buying.

\section{Difference in Quality}

Quality assessment by looking at the labels may reveal that not all products carry the same quality. There could be difference in ingredients, taste etc., which could result in price differences.

\section{Different Supplier Deals}

Some retailers drop the middleman (the distributor) and secure lower pricing directly from the makers.

\section{Market rivalry}

The supermarket industry is moving faster to accommodate changes in consumer shopping and eating patterns (Binkley, \& Connor, 1998). The emergence of warehouse stores, supercentres, and combination stores is threatening the traditional supermarket design. With a changing market environment, supermarket pricing practices may be changing as well.(Binkley, \& Connor, 1998). An alternative explanation is that sales result from retail competition because consumers are heterogeneous with respect to store loyalty (Hosken, et al 2000). According to Lal and Matutes (1989), multimarket rivalry substantially alters the nature of competition, especially when there are multiple goods. Competition from alternative retail forms expands possibilities of price discrimination, since different types of consumers may prefer different forms (Binkley, \& Connor, 1998).

\section{Consumer buying habits}

The Consumer buying habits in a trading area signal price elasticity. According to Becker's (1965) and Jones, E. (2003), retail demand elasticity may be related to consumer demographical behaviour such as age, education, income, frequency of product purchase, car ownership, and time of the week.

\section{Price signalling}

Different price mark-ups can also arise when prices of selected items are used to create a store price image, or "price signalling". Consumers most frequently compare store prices on milk, meat (e.g., ground beef, chicken), produce, and soda". With signalling, mark-ups no longer depend solely on product characteristics. Price signalling concentrates on consumer 
choice among stores rather than choice among products within a store (Binkley, \& Connor, 1998).

\section{Stress level}

According to Linda et al (1994) \& Lepisto, Stuenkel, \& Anglin (1991), the degree to which consumers are predisposed to stress can affect their perception of price. The manner in which the individual responds to stress constitutes the coping mechanism. When shopping, a stressed consumer may search for a lower price to serve as an indicator of a good purchase decision which will increase the consumer's inner sense of control and self-confidence.

According to Monroe, Grewal and Krishnan (1998), the pricing policy of retail stores plays a significant role in customer satisfaction, because price has the capability to attract or repel customers. Price functions as an indicator of quality. When prices are high, customers generally expect high quality. It can also suggest that they are being ripped off when prices are low, as customers may question the quality of products and services. The ability to match the supermarket price tread and the customer buying behaviour tread may signal the success of a supermarket, and the use of the right pricing strategy has its strength as promotional tool.

\section{Methodology}

In order to find out the pricing strategy adopted by the selected supermarkets, the magnitude of price fluctuations, and to explain the significance attached to the price in the retail mix by the customers, a triangulation methodology was utilised as it strengthened and confirmed results as noted by Owens, (1989) and Noor, (2008). This study evolved into three phases. In the first part, a shopping list of 30 grocery items was compiled. Items on the list were divided into food and toiletries categories. They represented basic items that most homes would purchase during a month. The categories were: canned foods, soups, cereals, beverages, starches, staples, cooking oil, soft drinks, bathing soaps, detergents, cake mixes, dairy, frozen foods, and miscellaneous items. The availability of the items and their use in pricing promotions as competitive tool by all the supermarkets as indicated by the "Knock " $\mathrm{n}$ drop " flyers was taken into consideration.

Volunteers were recruited for mystery shopping in the selected supermarkets with an aim to compare prices during the period of study. Each volunteer went to a different store and recorded the price for each item on the survey list on three different time of the month. The shopping list specified package size and brand. For comparison purposes, pre-determined sizes of the product and some name brands were used. Store specific brands were not included. The volunteers gathered data for the month of October 2015, during the first, middle and last week of the month. The 7 supermarkets visited for the study represented major supermarkets in Gaborone Botswana.

A mall intercept survey was carried to find out the role of price in supermarket choice in the retail mix, the time of the month shopping, and the brand choice by the customers. A total of 150 customers distributed across different malls were randomly surveyed. The mean and standard deviation were calculated on the prices per supermarket between the periods to get the 


\section{Macrothink Institute ${ }^{\mathrm{TM}}$}

tread. The mid-month price was used as the base. The survey data was cross-tabulated to get the shopping patterns and the role of price on time, brand and supermarket choice.

\section{Analysis and discussion}

Seven major supermarkets (a-to-g) were selected and surveyed with proportionate branches of each supermarket to find out the inert branch price differences in the selected products.

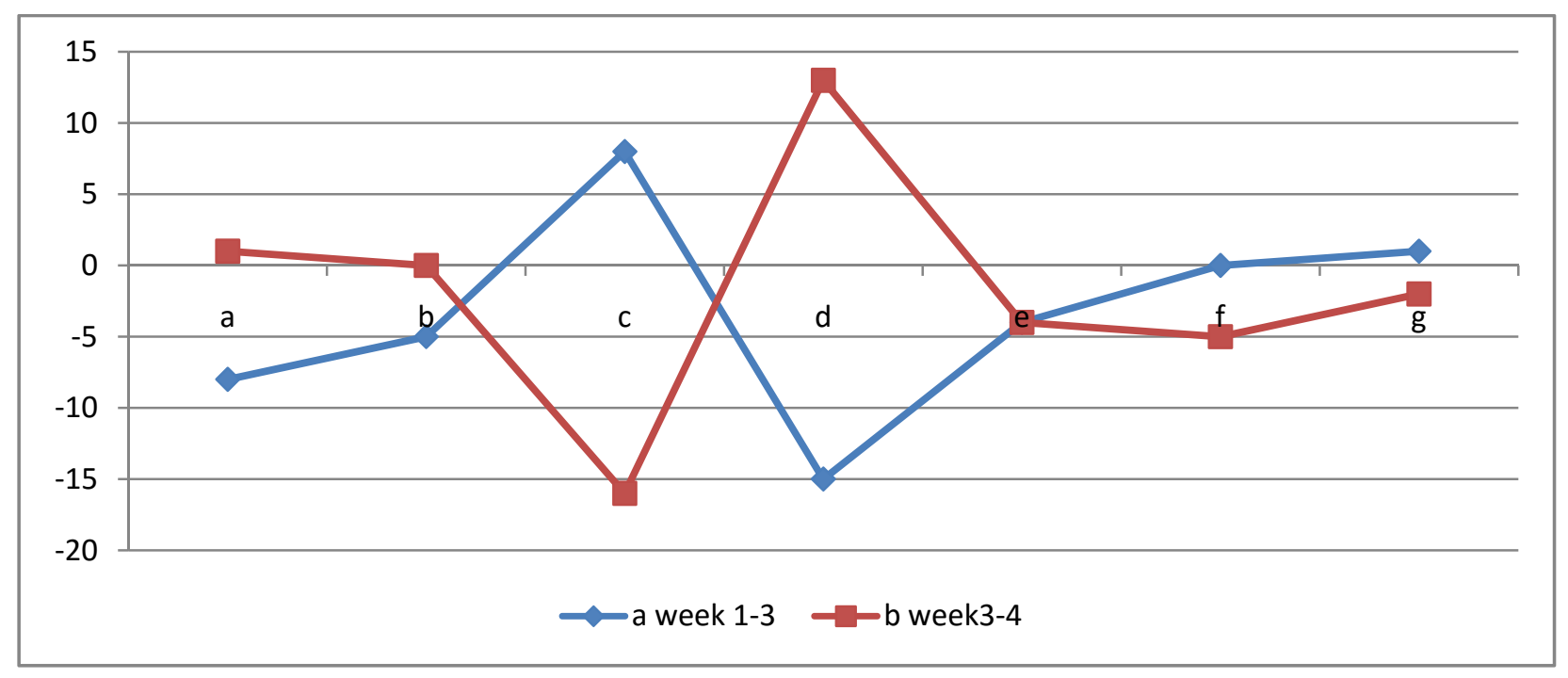

Diagram 1. Price trend across supermarkets

The price fluctuations across the supermarkets at the beginning of research period indicated a mean difference of between $1 \%$ to negative $8 \%$ in some supermarkets. A largely negative price change was observed between the early parts of the research period in all supermarkets as indicated in diagram above. However at the end research period, the fluctuation was higher. One supermarket had huge price increase, (d. with 13\% increase) while supermarket " $c$ " had negative $16 \%$ change. The other supermarkets had a moderate price increase compared to the beginning of the research period. This indicated a relative everyday- low -pricing strategy with a negative price increase on all the selected products.

\section{Price fluctuations with product brands}

Some products such as Sun flower oil (2 litres), clover milk (1 litres), white Star Maize Mill and Bokomo Wheat Flour had very stable prices across the period, and across the supermarkets. There was no price adjustment across the supermarkets. However brands like Dettol $750 \mathrm{ml}$ had a fluctuation of between mean averages of negative 5 to positive $8 \%$ across supermarkets, indicating its use in promo-marketing. Sunlight $2 \mathrm{~kg}$ detergent, Star Soft 2 litres, and MaQ 2 litres detergent had very high price movements as indicated on the table 1below: 
Table1. Comparison within categories

\begin{tabular}{|l|r|r|}
\hline Toiletries brands & \% mean change p-1 & \% mean change p- 2 \\
\hline Sunlight 2kgs & $-21.37 \%$ & $-1.33 \%$ \\
\hline Sunlight Auto 2kgs & $1.97 \%$ & $-8.50 \%$ \\
\hline Omo 2kgs & $1.87 \%$ & $-10.26 \%$ \\
\hline MaQ 2kgs & $-12.68 \%$ & $2.10 \%$ \\
\hline Ariel 2kgs & $3.59 \%$ & $-5.00 \%$ \\
\hline Handy Andy 750ml & $-7.26 \%$ & $-2.58 \%$ \\
\hline Star Soft 2Lt & $-15.18 \%$ & $-0.95 \%$ \\
\hline Air Roma 180ml & $-3.59 \%$ & $2.87 \%$ \\
\hline Dettol 750ml & $8.60 \%$ & $-14.95 \%$ \\
\hline
\end{tabular}

The categories of toiletries \&detergents products had the highest price reduction with price increase of negative $6.58 \%$ with Sunlight $2 \mathrm{~kg}$ detergent ranging from mean average of negative 21.37, MaQ $2 \mathrm{~kg}$ detergent negative 12.68 and Star soft with negative 15.18 . These indicate a general price reduction on the categories across the supermarkets. However Omo2 $\mathrm{kg}$ and Ariel 2kgdetergents had a relatively stable price across the supermarkets. The observation indicated that the two products had a lower preference than the rest. This could denote price competition on the fast moving products. 
Table 2. Comparison across categories

\begin{tabular}{|l|l|l|}
\hline Starch and Tea brands & \% change p- 2 & \% change p- 2 \\
\hline Super A1 5Kgs & $-5.32 \%$ & $0.84 \%$ \\
\hline Tastic $\mathrm{Kgs}$ & $-1.30 \%$ & $2.49 \%$ \\
\hline Tastic 5Kgs & $1.09 \%$ & $6.96 \%$ \\
\hline Tastic 10Kgs & $-7.89 \%$ & $18.52 \%$ \\
\hline Fatties and Monies spaghetti 1kg & $4.10 \%$ & $-10.89 \%$ \\
\hline Joko Tea bags 250g & $-6.40 \%$ & $0.27 \%$ \\
\hline 5 Roses tea bags 250g & $-14.13 \%$ & $0.56 \%$ \\
\hline Ricoffy 250g & $-4.07 \%$ & $9.29 \%$ \\
\hline Milk & & \\
\hline Clover Milk 1Ltr & $0.00 \%$ & $0.00 \%$ \\
\hline Cooking oil & & $0.00 \%$ \\
\hline Sun flower oil 2ltr & $0.00 \%$ & $0.00 \%$ \\
\hline Sun star 2Ltr & $-2.04 \%$ & \\
\hline
\end{tabular}

The researchers noted that the price change on the starch product had a positive price change over the period. Tastic rice of $10 \mathrm{kgs}$ and $5 \mathrm{kgs}$ had higher movement and the highest price increased over the period of $18.52 \%$ and 6.96 respectively. However, spaghetti that has a lower movement had a price and increase of $4.10 \%$ and later a reduction of $10.89 \%$ indicating an overall price decrease. Milk and cooking oil had a very stable price across the supermarkets and across the period under study. The products that appeared more on the knock ' $n$ drop fliers had higher price movements across the supermarkets than the rest indicating high usage of HYBRID strategy and PROMO strategies.

\section{Patterns of pricing with the same supermarket or between supermarkets}

It was observed that the price within the different branches of the supermarket was the same for most of the products. The supermarkets that are related also had same price for the products, indicating a pattern in pricing within the supermarkets. 


\section{Macrothink}

Table 3. Comparison of the single brand

\begin{tabular}{|l|l|l|l|l|}
\hline $\begin{array}{l}\text { Super } \\
\text { mark } \\
\text { et }\end{array}$ & Brand & Beginning & Mid Price in & \\
\hline a & Sunlight Auto 2kgs & Price in pula & Enda Price in pula \\
\hline b & Sunlight Auto 2kgs & 62.95 & 44.26 & 62.15 \\
\hline c & Sunlight Auto 2kgs & 31.45 & 41.45 & 41.45 \\
\hline d & Sunlight Auto 2kgs & 51.45 & 51.45 & 51.45 \\
\hline e & Sunlight Auto 2kgs & 62.95 & 52.95 & 52.95 \\
\hline & Average price & 52.95 & 52.95 & 52.95 \\
\hline
\end{tabular}

The price across the supermarkets however suggested lack of ant-price pattern as indicated by the table 3 above. The price of Sunlight Auto $2 \mathrm{kgs}$ ranged from 31.45 in supermarket ' $b$ ' to 62.95 in supermarket " $\mathrm{d}$ " which is almost double the price of a least expensive supermarket. The average price however indicates a pattern of lower prices in the middle of the month across the supermarkets. 
Table 4. Price variation between and within supermarkets

\begin{tabular}{|c|c|c|c|c|c|}
\hline Brand & $\begin{array}{l}\text { Mean price } \\
\text { over the period }\end{array}$ & $\begin{array}{l}\text { STDEV/ } \\
\text { Over the } \\
\text { period }\end{array}$ & $\begin{array}{l}\text { Super } \\
\text { market }\end{array}$ & $\begin{array}{l}\text { Mean price } \\
\text { over the } \\
\text { period }\end{array}$ & $\begin{array}{l}\text { STDEV/ } \\
\text { supermarkets }\end{array}$ \\
\hline \multicolumn{2}{|c|}{ Between supermarket } & & \multicolumn{2}{|c|}{ Within supermarket } & \\
\hline & Sunlight $2 \mathrm{kgs}$ & & & Sunlight $2 \mathrm{kgs}$ & \\
\hline Beginning & 31.95 & 6.93 & $\mathrm{e}$ & 40.95 & 1.00 \\
\hline Mid & 40.283 & 0.58 & $\mathrm{f}$ & 35.95 & 6.93 \\
\hline \multirow[t]{2}{*}{ End } & 40.62 & 1.15 & $\mathrm{~g}$ & 35.95 & 6.93 \\
\hline & Omo $2 \mathrm{kgs}$ & & \multicolumn{2}{|c|}{ Omo $2 \mathrm{kgs}$} & \\
\hline Beginning & 54.62 & 2.89 & & 45.95 & 1.00 \\
\hline Mid & 53.28 & 5.51 & & 43.95 & 3.61 \\
\hline \multirow[t]{2}{*}{ End } & 52.62 & 7.51 & $\mathrm{~g}$ & 46.95 & 0.00 \\
\hline & Tastic 5Kgs & & \multicolumn{2}{|c|}{ Tastic $5 \mathrm{Kgs}$} & \\
\hline Beginning & 54.62 & 2.89 & $\mathrm{e}$ & 58.95 & 1.00 \\
\hline Mid & 53.28 & 5.51 & $\mathrm{f}$ & 48.62 & 4.04 \\
\hline \multirow[t]{2}{*}{ End } & 52.62 & 7.51 & $\mathrm{~g}$ & 52.95 & 0.00 \\
\hline & Tastic $10 \mathrm{Kgs}$ & & \multicolumn{2}{|c|}{ Tastic $10 \mathrm{Kgs}$} & \\
\hline Beginning & 105.30 & 4.03 & $\mathrm{e}$ & 110.95 & 1.00 \\
\hline Mid & 102.28 & 9.02 & $\mathrm{f}$ & 97.96 & 8.67 \\
\hline \multirow[t]{2}{*}{ End } & 97.62 & 12.66 & $\mathrm{~g}$ & 96.28 & 5.77 \\
\hline & $\begin{array}{c}\text { Notwane Eggs } \\
2 / 18\end{array}$ & & \multicolumn{2}{|c|}{ Notwane Eggs 2/18 } & \\
\hline Beginning & 23.62 & 0.58 & $\mathrm{e}$ & 23.95 & 1.00 \\
\hline Mid & 23.95 & 0 & $\mathrm{f}$ & 25.95 & 3.46 \\
\hline End & 26.28 & 3.21 & $\mathrm{~g}$ & 23.95 & 0.00 \\
\hline
\end{tabular}

A lower mean price range was observed across the supermarkets, in the mid-month period. However the reduction indicated variations with standard deviation as indicated in table 4. A sample of five most used products in promotional pricing in three supermarkets indicated lack of uniformity in pricing between supermarkets. Some supermarkets dropped the price with high margins at the beginning and at the end of the period as denoted by the high standard deviations such in Sunlight $2 \mathrm{kgs}$ of 6.93 , Tastic $5 \mathrm{Kgs} 7.51$, Tastic $10 \mathrm{Kgs}$ 12.66. However, although the supermarkets used Notwane Eggs 2/18 prices for promotion, the difference between the supermarkets was not that high. This entails high use of price on selected product as leader pricing, for price signalling and high market rivalry between the supermarkets. Within the supermarket, only two supermarkets varied their prices significantly across the period for two products. The standard deviation for the remainder of the sampled products was not high, indicating consistency in pricing strategy across the period. 


\section{Mll Macrothink}

Table 4. Awareness of Special by consumers

\section{Consumer awareness on regular prices and specials}

\begin{tabular}{|l|l|l|}
\hline $\begin{array}{l}\text { Which week of the month do you } \\
\text { generally do shopping? }\end{array}$ & $\begin{array}{l}\text { Mean } \\
\mathrm{N}=150\end{array}$ & $\begin{array}{l}\text { Std. } \\
\text { Deviation }\end{array}$ \\
\hline Week 1 & 3.37 & 1.422 \\
\hline Week 2 & 2.11 & 1.364 \\
\hline Week 3 & 3.06 & 1.144 \\
\hline Week 4 & 3.22 & 1.461 \\
\hline Total & 3.12 & 1.413 \\
\hline
\end{tabular}

The research indicated that the consumers were aware of the weekly specials provided by the supermarkets. However, the awareness differed in the weeks, with mean of 3.37 being the highest in week one and the lowest of 2.11 in week 2 . This indicated that most of the specials were availed to the consumers at the end of the month or consumers were not interested in the specials after doing their monthly shopping in week one and four.

Table 5. The Weeks consumers shopped and the reasons for choosing a store

\begin{tabular}{|c|c|c|c|c|c|c|c|c|c|}
\hline \multirow{4}{*}{$\begin{array}{l}\text { Week of } \\
\text { the month } \\
\text { shopping }\end{array}$} & \multicolumn{8}{|c|}{ Reason for choosing the week to shop N150 } & \multirow{4}{*}{$\begin{array}{l}\text { Cleanliness } \\
\text { of the store }\end{array}$} \\
\hline & & & & & & Availability & & Availability & \\
\hline & & & & & Parking space & of imported & Staff & of almost all & \\
\hline & Low prices & Atmospherics & Location & Distance & $\&$, security & items & etiquettes & products & \\
\hline Week 1 & $4.21(1.122)$ & $3.56(1423)$ & $4.26(1.147)$ & $4.24(1.091)$ & $3.47(1.375)$ & $2.80(1.424)$ & $3.19(0.981)$ & $4.39(0.916)$ & $4.28(1.074)$ \\
\hline Week 2 & $3.40(0.894)$ & $3.87(1.356)$ & 4.14(0.900) & $4.20(0.919)$ & $3.25(1.488)$ & $2.62(1.302)$ & $3.50(1.309)$ & $4.56(0.726)$ & $4.56(0.726)$ \\
\hline Week 3 & $3.90(0.738)$ & $3.23(1.092)$ & $4.31(0.946)$ & $3.76(1.200)$ & $3.59(1.278)$ & $4.00(1.177)$ & $3.19(1.276)$ & $4.40(0.632)$ & $4.19(1.109)$ \\
\hline Week 4 & $3.86(1.240)$ & $3.41(1.378)$ & $4.09(1.164)$ & $3.98(1.340)$ & $3.05(1.548)$ & $2.64(1.479)$ & $2.98(1.470)$ & $4.24(1.146)$ & $4.45(0.974)$ \\
\hline
\end{tabular}

A survey of the consumers indicated that majority did their shopping in the first week, (a mean of 4.2), followed by week three with a mean score of 3.9, citing the low price as the reason for shopping then. These two weeks are the weeks that salary payment is made for most private and government employees respectively. It also follows that these were the weeks that the promotion sale was made in most supermarkets. However the highest mean score on why the consumer shopped at this period was on availability of products and the cleanliness of the stores with 4.56 and $(\mathrm{stdv}=0726)$ respectively indicating that though the lower price was important in the consumers mind, it was not the main reason that consumers 
choose a supermarket. In week three, price was secondary while the merchandise availability, location and cleanliness were primary in consumer store choice.

Table 6. Supermarkets consumers shopped in by week

Identifying Shopping Patterns among Consumers

\begin{tabular}{|l|l|l|l|l|l|l|l|}
\hline \multicolumn{2}{|c|}{$N=150$} & \multicolumn{3}{l|}{ Supermarkets } & & \\
Which week of & & & & & & \\
the month do & & & & & & & \\
you generally & & & c & d & f & g \\
\hline do shopping? & a & & & & & & \\
\hline Week 1 & $3.52(1.327)$ & $2.47(1.505)$ & $3.38(1.161)$ & $2.12(1.495)$ & $3.40(0.940)$ & $2.00(1.225)$ & $2.12(1.408)$ \\
\hline Week 2 & $2.56(1.236)$ & $2.67(1.658)$ & $3.12(1.126)$ & $2.11(1.453)$ & $3.89(1.054)$ & $1.56(1.130)$ & $2.13(1.642)$ \\
\hline Week 3 & $3.80(1.424)$ & $2.00(1.363)$ & $3.24(0.970)$ & $1.38(0.719)$ & $3.59(1.417)$ & $2.65(1.417)$ & $2.19(1.109)$ \\
\hline Week 4 & $3.93(1.104)$ & $2.39(1.434)$ & $3.79(1.237)$ & $1.73(0.933)$ & $3.12(1.531)$ & $1.93(1.237)$ & $2.44(1.198)$ \\
\hline
\end{tabular}

The above table indicates that Store (a) had the highest number of the customers across the weeks with mean score of 3.52 in week 1,3.93 in week 4, and 3.80 in week 3 . This may indicate that most customers did their end of the month shopping at this supermarket, which is followed by store (e). The store (e) had a mean score of 3.89 in week 2 which is opposite the store (a) shopping tread. Store (c) was the third favourite for the shoppers with majority of the customers doing their shopping almost evenly across the month with mean score of $3.38,3.12,3.24$ and 3.79 in successive weeks.

The study also observed from the available knock ' $\mathrm{n}$ drop promotional pamphlets that the two supermarkets "c and e" did the highest per average promotional pricing than the rest of the supermarkets. This indicated a relationship between the use of promotional pricing and shopping patronage.

\section{Discussion}

1. Supermarkets have a choice of either Everyday Low Price (EDLP that promises customers a low price without the need to wait for promotion or discount sale weeks. However, consumers did comparison shopping. Promotional and High-Low Pricing created excitement for customers doing end-of-the month shopping. On the other hand, Hybrid Pricing strategies used by the selected supermarkets resulted in higher patronage than the rest. The use Promotion pricing denoted that pricing play a bigger role as supermarkets' sales promotion strategy than normal pricing "P"' of the marketing 4 Ps. The supermarkets that managed to utilise the Pricing "P" more efficiently attracted more customers. However this may not translate to high profits as the reduction in price denotes a reduction in the margins which is usually very small in supermarkets, and this requires a delicate balancing. 
2. Price fluctuated across the supermarkets and across the selected commodities among identified supermarkets. The fluctuations, though attracted customers at week 1 and week 3 of the month, did not translate to an overall customer's attraction across the study period. The price promotion worked well when coincided with the pay period as indicated by Hansen (2006). Fluctuations also differed across categories confirming what was noted by Hosken, et al. (2000). In the rest of the period, the supermarkets attracted the customers with merchandise provision, quality of merchandise, location and store cleanliness, among other strategies.

3. The research noted clear patterns of pricing within the same supermarket and between supermarkets. All the supermarkets reduced their price in week 1 and week 3 while the other weeks the prices were generally high. The price of the merchandise though different in different supermarkets had similar range across the supermarkets, while it was almost the same in all the branches and related supermarkets.

4. Consumers had a high degree of awareness on regular prices and specials and did most of their end-of-the month shopping in the stores that extended the highest price reduction. At the same time, they did most of their shopping across the period with lower prices range. The research did not find any correlation between the Everyday Low Price (EDLP) and customer attraction. Customers were attracted more by the Hybrid Pricing which created lower pricing with sales promotion excitements.

5. While shopping patterns among consumers rhyme with the date they get paid, the research indicates that where there was suitable promotional pricing (hybrid), customer did their shopping across the month. Promotional pricing coupled with appropriate retail mix could result top high patronage across the seasons. Customers looked for the supermarkets that combined the promotional pricing with merchandise availability, and the atmospherics.

\section{Conclusion}

Hybrid pricing strategy is the most preferred pricing strategy in Botswana yielding better customer leg count than Everyday Low Price (EDLP) and High-Low Pricing. The cost oriented and demands oriented pricing strategies, though they work in the supermarkets, are used as background of the EDLP and H/L pricing. However, demand oriented pricing does apply to the fresh produce section, even though the Hybrid pricing strategy is the main strategy used.

There is a clear pattern in pricing which denote that the factors affecting the supermarkets in Botswana do so evenly across the supermarkets. This indicates that the survival of the supermarkets depends on the management's ability to utilise the pricing strategy in the retail mix providing the required products at the best prices on a better atmospherics.

Customers are well aware of the value for money and did go for the supermarkets that have additional value in terms of merchandise availability including Imported Items, Parking space \&, security, Cleanliness of the store, Distance and Location. With well-educated customer-base, EDLP and H/L pricing may not work as customers would be looking for the extras in the retail mix. 


\section{Limitations of the Study}

Due to time and fund constraints, the period of study had to be limited to one month and to limit the sample size of respondents to 150 consumers. The study indicates that there is scope for further research with a more extensive study covering a longer period with a large sample size and additional variables. A comparative study of pricing of supermarkets in Urban and Rural areas will also be of a great interest to relevant government authorities and policy makers.

\section{References}

Aumann, R. J. (1985). What is Game Theory Trying to Accomplish? Chapter 1 in Frontiers of Economics, edited by K. Arrow and S. Honkapohja, 28-76.

Azad, S.M.N, Hossain, MD, M., \& Parveen R, (2012). Customer Perception, Price and Demand Analysis of Supermarkets in Dhaka City: Journal of Business and Technology (Dhaka), 7(1), 35-51. http://dx.doi.org/10.3329/jbt.v6i2.14516

Binkley, J. K., \& Connor, J. M. (1998). Grocery market pricing and the new competitive environment. Journal of Retailing, 273-294. http://dx.doi.org/10.1016/S0022-4359(99)80096-7

Blattberg, R. C., Briesch, R., \& Fox, E.J. (2000). A benefit of congruency framework of sales promotions effectiveness . The Journal of Marketing, 64(4), 65-81. http://dx.doi.org/10.1509/jmkg.64.4.65.18071

Chen, S. F., Monroe, K., \& Lon, Y. C. (1998). The effects of framing price promotion messages on consumers's perception and purchase intentions. Journal of retailing, 73(3), 352-72. http://dx.doi.org/10.1016/S0022-4359(99)80100-6

Daun, W., \& Klinger, R. (2006). Delivering the messages ; how premium hotel brands struggle to communicate their value proposition. International journal of contemporary hospitality magement, 18(3), 246-52. http://dx.doi.org/10.1108/09596110610658643

Dondson, J. A., Typout, A.M., \& Sternthal, B. (1978). Impact of deals and deal retraction on brand switching. Journal of Marketing research, 5, 72-81. http://dx.doi.org/10.2307/3150402

Ellickson, P. B., \& Misra, S. (2008). Supermarket pricing strategies. Marketing Science, 27(5), 811-828. http://dx.doi.org/10.1287/mksc.1080.0398

Fassnacht M., \& Husseini S, El (2013). EDLP versus Hi-Lo pricing strategies in retailing-a state of the art article, Journal of Business Economics, 83(3), 259-289. http://dx.doi.org/10.1007/s11573-012-0648-y

General, I. M. D. (2002). Price differences for supermarket goods in Europe. Internal working document of the Internal Market Directorate General. URL: http://ec. Europa. Eu/internal market/economic-reports/docs/2002-05-price_en. pdf, 16(11). 


\section{Macrothink}

Journal of Management Research ISSN 1941-899X 2016, Vol. 8, No. 2

Goeree, J. K., \& C. A. Holt (2001). Ten Treasures of Game Theory and Ten Intuitive Contradictions. American Economic

Review, 91, 1402-1422. http://dx.doi.org/10.1257/aer.91.5.1402

Herrmann, R., Möser, A., \& Weber, S. A. (2009). Grocery retailing in Germany: Situation, development and pricing strategies (No. 41). Diskussionsbeiträge//Zentrum für internationale Entwicklungs-und Umweltforschung. http://hdl.handle.net/10419/39806

Hosken, D., Matsa, D., \& Reiffen, D. A. (2000). How do retailers adjust prices?: Evidence from store-level data. Federal Trade Commission.

http://web.shoprite.co.za/Shoprite-Africa/botswana-.html

http://www.accountingtools.com/high-low-pricing

http://www.africanadvice.com/Supermarkets_And_Grocery_Stores/Botswana/

http://www.mmegi.bw/index.php?sid=4\&aid=365\&dir=2013/August/Friday9

http://www.referenceforbusiness.com/history2/62/Pick-n-Pay-Stores-Ltd.html

http://www.thevoicebw.com/2010/12/24/heading-the-shoppers-chain/

https://en.wikipedia.org/wiki/Everyday_low_price

https://faculty.cit.cornell.edu/j12545/4160/presentation/groceries6.ppt

http://www.gov.bw/en/Ministries--Authorities/Ministries/Ministry-of-Trade-and-Industry-M

TI/MTI-News/Payless-makes-a-big-leap/)

https://en.wikipedia.org/wiki/Checkers_(supermarket_chain)

https://en.wikipedia.org/wiki/Shoprite_(South_Africa)).

Jones, E. (2003). An Application of Game Theory to Supermarket Pricing. Journal of Food Distribution Research, 34(1), 56-62.

Lal, R., \& Rao, R. (1997). Supermarket competition: The case of everyday low pricing. Marketing science, 16(1), 60-80. http://dx.doi.org/10.1287/mksc.16.1.60

Lal, R., \& Carmen M. (1989). Price Competition in Multi-market Duopolies. Rand Journal of Economics, 20, 516-537. http://dx.doi.org/10.2307/2555731

Lattin, J, M., \& Ortmeyer, G (1991). A Theoretical Rationale for Everyday Low Pricing by Grocery Retailers, Working Paper No. 1144.

Metobo, J. K. (2013). An Investigation of Pricing Strategies used by Supermarkets in Eldoret Town. International Journal of Current Research, 5(1), 090-093, January.

Munyoki, J. M. (1997). Analysis Of The Factors Affecting Pricing Strategies Of Selected Consumer Goods In The Retail Market: A Case Study of Supermarkets in Nairobi, Kenya (Doctoral dissertation, University of Nairobi). 


\section{Macrothink}

Journal of Management Research

ISSN 1941-899X 2016, Vol. 8, No. 2

Noor, K. B. M. (2008). Case study: A strategic research methodology. American journal of applied sciences, 5(11), 1602-1604. http://dx.doi.org/10.3844/ajassp.2008.1602.1604

Owens, R. G. (1989). A Triangulation Methodology in Research on Social Cultures.

Rajendran, K. N., \& Tellis, G. J. (1994). Contextual and temporal components of reference price. Journal of Marketing, 58, 22-34. http://dx.doi.org/10.2307/1252248

Reardon, T, Timmer, P., \& Berdegue, J, (2004). The Rapid Rise of Supermarkets in Developing Countries: Induced Organizational, Institutional and Technological Change in Agrifood Systems: Journal of Agricultural and Development Economics, 2, 168-183.

Shi, Y., Cheng, K., \& Prendergast, G. (2005). Behavioral response to sales promotion tools :a hong kong study. International journal of advertising, 24(4), 467-86. http://dx.doi.org/10.1080/02650487.2005.11072939

Weatherspoon, D, D., \& Reardon, T. (2003). The Rise of Supermarkets in Africa: Implications for Agrifood Systems and the Rural Poor: Development Policy Review, 21(3), 1-17. http://dx.doi.org/10.1111/1467-7679.00214 